\title{
Beyond school inclusion: secondary school and preparing for labour market inclusion for young people with disabilities in Spain
}

\author{
Maria Pallisera, Montserrat Vilà \& Judit Fullana \\ Department of Pedagogy, University of Girona, Girona, Spain
}

\author{
C/St. Domènec, 9 \\ 17071 Girona \\ e/mail: maria.pallisera@udg.edu, montserrat.vila@udg.edu, judit.fullana@udg.edu
}

(Received XX Month Year; final version received XX Month Year)

\begin{abstract}
Research analysing good practices in the area of labour market inclusion for people with disabilities shows that the role of the secondary school is fundamental in improving employment opportunities. The aim of this article is to analyse to what extent secondary education in Spain prepares young people with learning difficulties for later inclusion in society and the labour market. Results from studies into good practices in secondary education have established which educational characteristics to take into account for pupils' transition to working life and the need for the school to lead this process. We contrast these results with the current situation in Spain by comprehensively analysing how current secondary education is facing up to the challenges of labour market inclusion for young people with disabilities. Following this, we propose guidelines for the improvement of educational practices in secondary education so as to foster opportunities for labour market participation, from an inclusive viewpoint, for young people with learning disabilities.
\end{abstract}

Keywords: social inclusion; secondary education; people with learning disabilities; school to work transition

\section{Introduction}

Social inclusion is a process that should ensure all members of society, whatever their personal characteristics, participate equally in the different social spheres: the political, economic, work, cultural, etc. Active social inclusion therefore presupposes fighting 
against poverty, promoting the participation of all members of society in the labour market and their access to high-quality social services (health, housing, education, justice). From this theoretical prospective, then, work is not the only domain in adult life, and it should therefore not be the fundamental objective of transition to adulthood. Nevertheless, analyses of the experiences of people with learning difficulties being integrated into the labour market in ordinary jobs confirms that work is one of the most powerful motors in helping disabled people to construct their identity as an adult member of the community. When integration processes are carried out with care and the necessary support, the context of work constitutes a domain that favours quality of life (Verdugo and Vicent, 2004), increased self-esteem, the planning of future projects, and improved sociopersonal skills (Pallisera and Rius, 2007; Rius, 2005).

Inclusion in society and the workplace remains a difficult challenge for people with disabilities. The situation is also complex in Spain, if we take into account the latest official data. Thus, the Survey on Disability, Personal Autonomy and Situations of Dependence (Encuesta de Discapacidad, Autonomía personal y situaciones de Dependencia) carried out by the Instituto Nacional de Estadística (National Statistics Institute) for 2008 and 2009 shows that in 2008 only $28.3 \%$ of the disabled population of working age is in employment. Of those people with disabilities who work, most are people with hearing and sight disabilities. Those who demonstrate lowest percentages of employment are people with learning difficulties.

An analysis of labour market integration processes for people with disabilities cannot be conducted without context. Two situations have recently converged to affect the situation facing disabled people in Spain when it comes to labour market integration. Firstly, trends in new labour relations caused by the progressive expansion of globalisation processes and the new economy. Secondly, the impact of the current global economic crisis on our country. The first of these two factors has over recent years led to work in companies progressively involving more new technologies and therefore the loss of unqualified jobs. This particularly affects people with disability, who in our country tend towards labour market integration in occupations that require low levels of training (the hotel and catering industry, commerce and services) (Colectivo IOÉ, 2003). The economic boom at the beginning of this century and specifically the explosion of the construction industry and related sectors in our country 
compensated for the loss of low-qualified jobs from companies. However, the current economic crisis is having a critical effect on Spain, with unemployment rates now rising above $20 \%$. One recent study conducted by the Spanish Committee of Representatives for People with Disabilities (Comité Español de Representantes de Personas con Discapacidad or CERMI, 2009) highlights that the worsening of the economic situation and fall in business investment is particularly affecting the more vulnerable groups in Spain, as is the case with disabled people. Aguilar (2010) considers that in 2009 recruitment of people with disabilities decreased by $15 \%$ and that their rate of unemployment is 4 times higher than that of other workers. He also confirms that the type of work done by this group is low-qualified, with lower incomes which condition opportunities for social participation. The current cuts in public spending and education affect, as well as families, schools and bodies that support labour market integration, producing a vicious circle that leads to elements of social exclusion in this group. One ray of light in this dark panorama is the fact that the service sector, where most people with disabilities work, is the one which is currently showing greatest signs of growth in Spain (CERMI, 2009).

Although the current economic climate clearly does not favour labour market inclusion for people with disabilities, the crisis is not the only cause of this situation. Different sources point to one explanation for such a high percentage of unemployed disabled being the lack of training among this group. Thus, the Instituto Nacional de Estadística (National Statistics Institute) (2009) shows that only 19.2\% of the disabled population currently aged between 25 and 44 has completed compulsory secondary education. A deficit in terms of education clearly makes labour market inclusion difficult for people with disabilities, especially within a context characterised by competitiveness, precariousness and flexibility. (Astarloa and Liébanas, 2002; Jiménez Lara, 2002).

Various studies on labour market inclusion for people with disabilities (Jordán et al, 2005; Pallisera and Rius, 2007; Vilà et al, 2007) contribute data regarding the factors that facilitate labour market inclusion. Although multiple factors combine to influence an individual's path towards inclusion in society and the labour market, the level of education of the disabled person is confirmed as a key element in inclusive processes. The period of compulsory secondary education is particularly significant in its 
constituting the educational scenario in which all young people plan their future projects and take decisions relating to their transition to adult life.

Thus, establishing objectives related to labour market inclusion for young people with disabilities involves analysing the educational scenario in which these young people experience their educational process. This is an area which has received little attention in Spain. Although in recent years, and coinciding with the arrival of disabled pupils in ordinary secondary schools, different contextualised studies have begun to appear (Martínez Domínguez, 2005; Arnáiz, 2009; Echeita et al, 2009), most of these focus on studying methodologies that favour inclusion at the stage of secondary education. We do not, however, find studies focusing on how the education received by pupils with disabilities during compulsory secondary schooling is facilitating their labour market inclusion. This focus is absolutely necessary, given that it is work done during the stage of secondary education that will determine to what extent young people with learning difficulties will have more and better opportunities to join the labour market.

The aim of this article is to analyse how far secondary education prepares young people with learning difficulties for their later inclusion in society and the workplace. The second section presents what from the research can be interpreted as guidelines for good practices in secondary education with regard to facilitating labour market inclusion. In sections three and four we analyse the current situation experienced by young people with disabilities in secondary education in Spain, determining, on the basis of research carried out within this context, how it responds to their future needs with regard to labour market inclusion. Finally, we propose recommendations for improving educational practices in secondary school education in order to facilitate opportunities for labour market participation, from an inclusive viewpoint, for young people with learning disabilities.

\section{Secondary education and labour market inclusion. What does the research tell} us?

Two main lines of research provide data on the role of the school in labour market inclusion for young people with disabilities. On the one hand, there is research that focuses on labour market inclusion processes for people with disabilities, which identifies the factors that influence good practices in this area and proposes what work 
should be done in education and the education system to favour the potential employment of young people (Alomar, 2004; Colectivo IOÉ, 1998; Rius, 2005; Vilà et $a l, 2007)$. Some of the findings from this line of research coincide with the results of studies conducted for over two decades in the field of transition (Hudson, 2006; Kohler and Field, 2003; Rusch et al, 2009; Winn and Hay, 2009). Such a focus constitutes the second line of research which involves studying all of the scenarios related to inclusion in society and the workplace as one, whether they form part of the education system or the post-school arena. More extensive than the partial view awarded by research focusing on just one scenario or the other, it provides a global view of the process that leads to objectives being fulfilled, specifically influencing the planning of said process and what is required in terms of coordination.

The results of studies carried out in both areas agree on the main lines of action that must be addressed in education in order to foster labour market inclusion for young people with disabilities:

- Promoting the inclusion of sociopersonal components on school curriculums

In Spain in recent years various in-depth studies have been conducted into the evolution of labour market integration processes for people with learning difficulties (Alomar, 2004; Rius, 2005; Pallisera et al, 2005; Vilà et al, 2007). Alomar (2004) uses the case study method to analyse the behaviour of personal, work-related and social variables that may help to predict the success of a worker with learning difficulties adapting to their work in an ordinary company under the Spanish system of Supported Employment. Rius (2005) also conducted a case study focusing on people with learning difficulties working in public administration under the same system. The study provides an in-depth analysis of the relationship between the different dimensions involved in pathways to labour market integration. Pallisera et al (2005) present the methodology and main results for three studies focusing on labour market inclusion processes through what is known in Spain as "employment with support". These studies are linked together in one continuous process aimed at determining the weight of the different factors representing basic elements in the success of said inclusion processes. Using a qualitative methodology, we attempt to ascertain how different factors (family, education, employment setting, continued employment, etc.) may explain greater or lesser success in the labour market inclusion process. Vilà et al (2007) specifically 
present elements that favour labour market inclusion processes, among which training or education prior to employment plays a fundamental role. In these studies, the labour market agents and experts who support labour market integration who were interviewed completely agree that the key abilities for smooth integration, regardless of the sector, are those sociopersonal skills that lead to autonomy in the workplace. These include the ability to take decisions and accept instructions, exercising responsibility, demonstrating a balanced level of self-esteem, empathy in social relationships and ability to adapt to the environment and possible changes, problem-solving in the workplace, all skills awarded enormous value in the world of work. These skills form a part of the components considered to be key in self-determination: decision-making, problem resolution, the ability to establish objectives, abilities relating to independence, risktaking, self-observation, evaluation and support, self-instruction, self-defence and leadership, internal locus of control, positive attributes with regard to efficiency and expectations of results, self-awareness and self-knowledge. (Wehmeyer, 1998).

In Spain, practically no studies have been conducted to analyse the role of selfdetermination in transition processes to working life. By contrast, in other countries, such as the United States, different studies have been carried out to establish the link between a greater command of abilities relating to self-determination and the greater or lesser achievement of results in one's own objectives in adulthood (work, independent life, community participation). Thus, Wehmeyer and Schwartz (1997) and Wehmeyer and Palmer (2003), in studies that relate level of self-determination to achieving positive objectives in adult life, conclude that pupils with a higher score in self-determination tests demonstrate greater probability of obtaining employment and a higher salary after completing their education. Both of the above involved longitudinal studies in which data on self-determination was collected a year prior to the end of secondary education, contrasting these with the situation one year after data collection in the former case and three years in the latter. Students who were more self-determined fared better across multiple life categories, including employment, financial independence and independent living. Test et al (2009) carried out a systematic review of research to identify predictors for positive postschool outcomes in pupils with learning difficulties in the fields of education, work and independent life. Self-advocacy and self-determination were confirmed as two of the predictors of improved outcomes for both postschool education and employment. Martin et al (2007) and Trainor (2008) document diverse studies that 
highlight the importance of self-determination as a key factor in providing pupils with the best opportunities for inclusion after secondary education. These approaches create a new challenge for the relationship that has prevailed until now in educational scenarios: preparing for self-determination means listening to young people with disabilities and actively involving them in decisions that affect their life.

- The role of schools in transition processes that lead to social and labour market inclusion

As Winn and Hay (2009) point out, a common characteristic of transition processes in different countries is the existence of multiple services. This considerably increases the complexity of the coordination processes required to facilitate positive routes to employment. In light of this complexity, it becomes apparent that there is a need to both clarify the allocation of responsibilities among agents who intervene in different scenarios (school and post-school), and to establish a resolute and efficient leadership, without which the processes of transition to adult life are far more likely to fail (Hudson, 2006).

Experiences in different countries demonstrate the need for coordination between various organisations during the period of school education: thus, federal legislation in the US has included specific plans for facilitating transition since 1983, and since 1997 all IEPs (Individualised Education Programmes) include an individualised needs analysis regarding transition from the age of 14 onwards, two years before the end of compulsory education (Kohler and Field, 2003; Rusch et al, 2009). In the UK, it is compulsory to hold specific meetings to plan transition during the final year of schooling, and specific protocols are available for facilitating coordination between organsiations involved in the transition process (Kaehne and Beyer, 2009).

The secondary school represents the key element in leading the transition process (Rusch et al, 2009). As an educational institution it is in a unique position due to its easy access to families, its knowledge of young people and the trained professionals it has available to it. From its different spheres of influence (educational, relational, planning and coordination of the agents involved), the secondary school therefore constitutes a fundamental arena for promoting opportunities of labour market inclusion for young people with learning disabilities. 
In order to analyse how current secondary education is facing up to the challenges of labour market inclusion for young people with disabilities, we contrast these findings with the current situation in Spain.

\section{The Spanish context: keys to understanding the secondary stage and its role in transition to working life for young people with learning difficulties.}

With the political transition and re-establishing of democratic institutions that followed the dictatorship it was not until 1982 that the Spanish parliament approved Act 13/1982 on the Social Integration of the Disabled (Integración Social de los Minusválidos or LISMI). The basic idea behind the LISMI is that measures aimed at promoting the educational, cultural, occupational and social life of people with disabilities be implemented by means of their integration into non-specialised organisations, except when individuals conforming to given characteristics require specific attention from special services or centres.

It was the 1990 General Statutory Law on the Education System - known as LOGSE however, that established and reinforced the principles on normalisation and integration included in the previous law and introduced the concept of special educational needs into the legal system. After this point, special education was no longer considered to be the education of a different type of pupil, but came to be understood as the set of material and human resources made available to the education system so that it might respond appropriately to the needs that some of its pupils may evidence.

Finally, it is also worth referring to Statutory Law 2/2006 on Education (LOE), which enhanced the existing conceptual framework, introducing the concept of equality, by specifying those groups of pupils that require a different type of educational care to ordinary schooling because they demonstrate a specific need for educational support. It also established the resources required to this end to achieve the full inclusion of said pupils.

If we focus on educational practice and the attention received by pupils with special educational needs in Spain, one of the key processes is deciding where to place these pupils. It is currently the responsiblity of educational guidance teams (generally external 
to the school and multi-professional) to gauge what support pupils may need by evaluating their personal, school and family conditions. At the present time, we can say that pupils either attend ordinary schools equipped with the necessary resources and measures, or special education centres. An "intermediate" solution is what is known as shared schooling, which, although legally constituting an extreme measure aimed at those pupils who in addition to poor academic performance suffer serious behavioural disorders, is actually often being used without this latter condition necessarily being the case.

Secondary education is compulsory in Spain from the ages of 12 to 16 . During this stage, different organisational, curricular and methodological resources and measures exist to attend to the specific needs of pupils in secondary education. Among these we find the Tutorial Action Plan, Individualised Plans, Specific curricular diversification programmes (shared schooling units) and Special education support units (SESU). Equally, there are also professionals and services to attend specifically to these pupils in this stage of their education; in reference to professionals, we would highlight those specialising in psychology and pedagogy (permanently employed in secondary schools), teachers in charge of the SESU, special education assistants and educators, social integrators, etc., and in reference to services, educational guidance teams, pedagogical resource centres, specific resource centres: for pupils with hearing and visual difficulties, serious motor and access disorders, serious general development disorders and behavioural disorders.

Data provided by the Spanish Ministry of Education on the schooling of pupils with disabilities in secondary education in the first decade of the 21 st century show that there is generally little variability in the number of pupils with disabilities schooled at special education centres or in special education support units (SESU) attached to ordinary schools, this figure being around $0.4 \%$ of all pupils enrolled in compulsory education. There is an even distribution of these pupils between state and private schools, and more pupils with learning difficulties receive special schooling than those with hearing, sight or motor disabilities.

Between $1.29 \%$ and $1.45 \%$ of all the pupils in secondary education are pupils with special educational needs enrolled at ordinary secondary schools. As was the case with pupils schooled at special education centres it is the pupils with special educational 
needs grouped under the category of "learning difficulties" who have the highest presence in ordinary compulsory secondary education. ${ }^{1}$

The official data offer us a general view of the schooling received by pupils with special needs in secondary education. However, a lack of research into the training received during this stage of education and the strategies adopted to promote the labour market integration of pupils with disabilities led us to carry out the study presented in the following section.

\section{What schools do to promote labour market inclusion. Research findings}

As already mentioned, very little research exists on training received by people with learning difficulties in Spain. Having conducted different studies relating to labour market inclusion for people with disabilities (Pallisera et al, 2005) and provided evidence of the important role played by the educational context in transition processes (Vilà et al, and 2007), we specifically focused this research on how secondary education is currently preparing pupils with disabilities for their future labour market inclusion (Vilà, 2008) ${ }^{2}$. The study has two main aims: firstly, to conduct an analysis of the education or training that receive the pupils with disabilities in relation to future labour market inclusion during compulsory secondary education; secondly, and on the basis of the analysis we have conducted, to propose actions for secondary schools, for improving the occupational potential and opportunities for labour market inclusion of pupils with disabilities. Given the lack of data available in our country, this study constitutes a first step towards researching this area in some depth.

Bearing in mind that the number of pupils with disabilities receiving schooling in secondary education is fairly low and the resources we had available for our research, we focused the study on schools located in our own Autonomous Region, Catalonia.

\footnotetext{
1 Data from the Spanish Ministry of Education's statistical database (http://www.educacion.es/mecd/jsp/plantillasjsp?id=31\&area=estadisticas)

2 The title of the study is "Analysis of labour market inclusion training for people with disabilities in secondary education in Spain. Proposals for action to improve social and occupational training." Project funded by the Ministry for Education and Science (Period 2005-08). SEJ2005-01957/EDUC.
} 
The Catalan Board of Education provided us with data on the schooling of pupils with disabilities in secondary education during the 2006-07 academic year. Based on the criteria of school size, size of population where the school is located, type of school network (state/private), type of secondary education taught (compulsory secondary education, post-compulsory, professional training), we selected 18 secondary schools, from 7 different locations. During the academic year subject of study, the 18 schools attended to a total of 75 pupils with disabilities, 25 of whom had learning disabilities and were studiing compulsory education.

A field study was carried out in the form of visits to the schools and interviews with the professionals working there. The interview gathered information related three different subject areas. The first was aimed at collecting descriptive information on the school: location, type of school (state/private), type of teaching, number of pupils and units (number of classrooms). The second area included data on social and occupational training offered to pupils. The aim of the latter was to determine whether the school's curriculum integrated teaching and learning experiences for promoting social and occupational training and to what extent pupils with disabilities benefited from these experiences; that is, whether they take part in social and occupational programmes organised for all pupils at the school or whether they receive specific training aimed at their needs with regard to labour market and social inclusion. Lastly, the third block of questions was intended to gather personalised data on all pupils with disabilities at the school in order to obtain information regarding their school progress, the parameters conditioning the attention they received at the secondary school and forecasts for the future.

The interview was subjected to a validation process by a panel of judges. Five experts in areas related to educational inclusion at school and three experts in research methodology assessed the suitability of the questions to the aims of the interview. A pilot study was carried out at two schools, leading to the drafting of the definitive version of the instrument.

The interviews were conducted by 4 members of the research team between January and May 2007. Prior to the visit, we sent a letter to schools to explain our aims and called by phone to agree the date and time of the visit, as well as which member of the teaching staff would be interviewed. The interview was conducted with a member of the 
management team of each school. Interviews were recorded and transcribed. A quantitative analysis was conducted for descriptive data relating to the school (type of school, type of teaching, number of pupils per year and number of classrooms) and to those pupils with disabilities at the school (year of birth, type of disability, school year). Open responses referring to how the curriculum was organised, the pupil's timetable, the type of support received, and their assessment of the social and labour market integration training they received were analysed using content analysis techniques. The results of the study are explained briefly below.

\section{Results}

Firstly, the study provides information regarding how the educational care received by young people with learning difficulties is organised in secondary schools. The second point of focus is the labour market integration training received by these pupils. Finally, a brief reference is made to the role played by secondary schools in the transition process.

- The organisation of educational care received by young people with disabilities

The first decision schools need to take that will condition the subsequent care provided, is where to place these pupils. As we have already mentioned, different options exist for curricular diversification in secondary education. Table 1 shows the distribution of pupils in our study according to how their educational care is organised.

\section{(Table 1)}

We observe that all pupils with learning difficulties follow adapted curriculums, and that the vast majority are placed in one of the various options existing for specific educational care outside their ordinary school group. These figures agree with the trend, corroborated in other studies in our context (Arnáiz, 2009; Escudero et al, 2009; Martínez Abellán et al, 2010), of young people with learning difficulties spending at least half of their school day in a classroom specifically designed for young people with learning difficulties. It is important to highlight that this trend is in keeping with the general practice followed by secondary schools of grouping their pupils into different classes according to academic results from Year Three onwards. Within this dynamic, the special classroom is incorporated as a place specifically for - and attending to the 
different needs of - young people with disabilities. This trend must by no means be understood as a policy of the Board of Education, but rather constitutes the method the schools themselves choose to organise pupils.

- Labour market integration training

If we specifically analyse the data obtained for labour market integration training provided by schools with pupils with disabilities, the first observation worthy of note is that none of the schools have a specific organised approach to labour market integration training in secondary education. Those actions that are implemented have the following characteristics:

- Actions are mostly concentrated in the final year of secondary school. Only in 3 schools did they begin in Year 3.

- They are short in length, and tend to be framed within the Tutorial Action Plan aimed at all pupils.

- They tend to consist of: general sessions aimed at presenting the different options available at the end of secondary school or talks about different types of jobs. Some schools implement specific actions: for example, one of them has a vegetable garden and pupils on the adapted curriculum follow a compulsory programme whose objective is to look after the garden. In another centre, actions are implemented to provide guidance in self-knowledge and exploring professional interests, attitudes and expectations. Only in two schools are specific actions implemented in relation to social skills training.

The above actions are not specifically for pupils with disabilities, but are aimed at all pupils. Specific actions for pupils with disabilities consist of individual interviews aimed at studying the possibilities of their being transferred to other services after completing secondary education.

Such actions are no doubt necessary, but we believe there is a more serious issue. If we take into account the findings of research into content directly related to labour market inclusion, we observe that sociopersonal skills and self-determination are not explicitly considered on the syllabus. Only at two of the schools we visited were activities implemented that were related to these objectives, specifically, social skills training 
programmes. This does not mean that content considered fundamental for later inclusion is completely ignored; areas such as self-esteem, responsibility, decisionmaking, etc., are of a markedly transversal character. Nevertheless, their explicit inclusion on the syllabus is the only guarantee that these skills will be sufficiently developed with these pupils.

In the study we conducted, we observe that schools do not perceive the labour market integration of young people with disabilities as a priority to be worked on at school, except in cases where transition is immediate (that is, in the final year of secondary school). The main concern would seem to be how to work with the young person at the school to improve their learning, performance and, if possible, how they relate to other people. There is no awareness, however, that future opportunities in labour market integration depend on the work done during this period of their education.

Paradoxically, the results of our research show that most pupils schooled at ordinary schools, and regardless of where they are placed, follow an adapted syllabus which is clearly dominated by the academic content on the secondary syllabus. Schools group pupils separately into specific classes, which provides the opportunity to work with fewer pupils. They do not, however, take advantage of this to work on specific content related to later labour market inclusion - a fundamamental aim for most pupils with disabilities who are not going to continue with academic education - but rather to adapt the syllabus, which, as Escudero (2005) points out, has a clearly academic focus in Spain.

- The role of schools in the transition process to working life

Above and beyond strictly educational issues, analysis of the role of secondary schools in leading the transition processes towards labour market inclusion demonstrates that schools are a long from achieving this at the present time. The basic indicator here is the scarce involvement of other teachers at the school when it comes to educating young people with disabilities. At all the schools we studied, the only teachers who work with young people with disabilities are those who have this as their specific purpose (the head of the class for young people with disabilities, the school educational psychologist, etc.). Decisions regarding how to work with young people with learning difficulties focus primarily on taking decisions about where they will be taught and the organisation 
of staff for teaching them. Once the decision has been taken regarding where to place pupils, they are considered the exclusive responsibility of the specialised teacher. Other studies carried out in Spain agree with this finding. Thus, Martínez Domínguez (2005) states that the application of exceptional measures to respond to diversity and the incorporation of new permanent positions in schools has not led to improved teamwork involving these teachers and what they do at the school. Quite the contrary, a dual culture has been established between the teachers specialised in ordinary content and teaching methods and teachers specialised in special subjects and programmes.

The initial training secondary school teachers receive in Spain doubtless goes some way to explaining the difficulties schools face in promoting transition processes. The only training secondary teachers used to receive in this country consisted of a brief pedagogical training course following their university studies in their specialised academic area. It was not until the 2009-10 academic year that the Master's in Secondary Education was introduced in accordance with directives from the European Higher Education Area. Sánchez Palomino (2007) has conducted research on secondary school teachers, specifically analysing training, attitudes, beliefs and ideas related to educating pupils with special needs upon completion of the aforementioned pedagogical course. We will only mention a couple of the results of this research here: over $90 \%$ of future teachers surveyed consider that the education of pupils with special needs is more effective in specialised centres; furthermore, $96 \%$ consider the attention that pupils with disabilities receive at an ordinary school to be the work of specialists. This is clearly not an ideal starting point for focusing the education of pupils with disabilities on the transition process, nor for schools to have the leadership required to coordinate processes for ensuring successful transition processes.

\section{Building bridges for labour market inclusion from schools. Recommendations for policy and practice.}

The aim of this paper is to analise to what extent secondary education in Spain prepares young people with learning difficulties for later inclusion in society and labour market. Results from studies into good practices in secondary education have established some of the main educational characteristics to take into account. These demonstrate that sociopersonal and self-determination skills play a key role in achieving objectives 
related to adulthood. They also reiterate the importance of secondary schools exercising leadership in transition processes.

As we remarked in our introduction, the current economic climate in Europe and particularly in Spain increases the risk of exclusion for people with disabilities (or makes their integration into society and the labour market more difficult). While recognising that work is not the sole objective of adult life, the current situation means that today more than ever there is the need for training to offer young people with disabilities as many resources as possible for their integration into the labour market. With this in mind, adequate training is a necessary condition, although not sufficient in itself.

Reducing discrepancies between the reality we have observed in Spain and the educational scenario required to promote labour market inclusion processes entails adopting different measures.

Generally speaking, the Spanish education system has made significant progress in recent decades in its commitment to inclusion. It must logically, however, continue this progress so as to ensure an adequate educational response for all pupils (at any stage of their education). This must entail the full assumption of the inclusion principle and the conviction that only by these means can it guarantee development and equality for all, and therefore greater social cohesion.

Our first recommendation refers to the essential role of educational policy. Firstly, a legal framework is required to clearly establish secondary schools' responsibility in the processes of transition to a life of work. Our analysis has revealed that schools have numerous resources for attending to diversity; however, there is currently a lack of directives to clarify the role of the school when it comes to leading processes necessary for inclusion in society and the workplace. Specifically, educational policies are required that achieve the following: firstly, to explicitly recognise the primary role of secondary schools in promoting the inclusion of young people in the labour market, and secondly, while respecting the autonomy of schools and the decision-making powers of its professionals, to establish specific guidelines regarding a syllabus for facilitating inclusion, when to work on this and schools' responsibility in leading the necessary coordination processes. 
Our second point, which also requires government intervention, is the need to establish guidelines on specific actions facilitating labour market inclusion to be implemented during compulsory secondary education that take into account the results of studies focusing on good practices in this area. Thus, the need must be established to include learning experiences in sociopersonal skills and self-determination on the secondary syllabus, with guidelines to ensure their inclusion throughout the period of schooling. Educational programmes must also be designed for all young people with disabilities, specifying activities required to meet the aims of transition to adult life from an inclusive perspective. The young person in question must also be included in the compiling, monitoring and evaluation of these programmes, and he or she must have a say in related decision-making processes.

Thirdly, our analysis demonstrates that teaching staff in this country are currently not sufficiently committed to the education of young people with disabilities. Such a commitment is necessary, however, if the secondary school is to act as a leader and implement the educational actions required for more effective work on labour market inclusion. Increasing teacher involvement and working on components related to selfdetermination for young people with disabilities will require changes in attitude and appropriate training that respond to the new realities in education. In order to construct this new educational scenario, it is essential that teachers participate in training processes supported and facilitated by the Board of Education.

Fourthly, it is important that the concept of social inclusion be accepted and that training not be focused solely on achieving work-related objectives. The need must be taken into account for educational processes to address training for full social participation in different areas (relationships, leisure, independent life, work, etc.). This idea will, however, in all likelihood require different departments to jointly design policies that provide guidance for implementing the necessary measures for social inclusion.

Finally, for a fuller understanding of the relationships and discrepancies existing between the scenarios and main actors involved in processes leading to people with disabilities being included in the workplace, research will be required into the full complexity of these processes, including, and this is an essential point, contributions 
from people with disabilities themselves. One element that would therefore contribute decisively to building bridges towards labour market participation from an inclusive viewpoint would be research that takes a more generalised view and includes the participation all of those involved in these processes, including both the secondary school and post-school arena. This is a focus that has barely been addressed in this country.

Short biographical notes on all contributors

Maria Pallisera

BSc in Education (1989), Autonomous University of Barcelona (AUB). PhD in Education (1994) (University of Girona). Assistant Professor (1990-1994) and Associate Professor since 1996 at the Department of Pedagogy, University of Girona (Spain). Her research interests includes social inclusion of people with disabilities, supported employment processes as a way of work inclusion and transition to adult and active life of people with learning disabilities. She has co-authored a number of papers on these areas.

Montserrat Vilà

BSc in Education (1986), Autonomous University of Barcelona (AUB). PhD in Education (1996) (University of Girona). Assistant Professor (1988-1999) and Associate Professor since 1999 at the Department of Pedagogy, University of Girona (Spain). Her research interests includes inclusive education and social inclusion of people with disabilities She has co-authored a number of papers on these areas.

Judit Fullana

BSc in Education (1989), Autonomous University of Barcelona (AUB). PhD in Education (1995) (University of Girona). Assistant Professor (1990-1996) and Associate Professor since 1997 at the Department of Pedagogy, University of Girona (Spain). Her research interests includes inclusive education and social inclusion of people with disabilities. She has co-authored a number of papers on these areas.

Postal address of the autor who will check proofs and receive correspondence Dr. Maria Pallisera

Universitat de Girona.

Facultat d' Educació. Departament de Pedagogia.

Plaça Sant Domènec, 9

Office 321 
Tel: +34 972-418352

17071 Girona (Spain)

e-mail: maria.pallisera@udg.edu

\section{References}

Alomar, E. (2004) El treball dels joves amb retard mental en entorns normalitzats: anàlisi d'una realitat de treball amb suport. Doctoral disertation, Barcelona: Universitat Ramon Llull.

Aguilar, R. (2010) La crisis hunde el empleo para los discapacitados. Público.es. (212-2010). http://www.publico.es/espana/296554/crisis/hunde/discapacitados. (3-32010)

Arnáiz, P. (2009) Análisis de las medidas de atención a la diversidad en la Enseñanza Secundaria Obligatoria. Revista de Educación. 349, 203-223.

Astarloa, A. \& Liebanas, A. (2002) Los actores del empleo privado. Panorámica y propuestas sindicales sobre el empleo de personas con discapacidad. In Empleo privado de las personas con discapacidad. Documentos 6, pp. (81-107). Madrid: Real Patronato sobre Discapacidad- Ministerio de Asuntos Sociales.

CERMI (Comité Español de Representantes de Personas con Discapacidad) (2009). El impacto de la crisis económica en las personas con discapacidad y sus familias. Madrid: Ed. Cinca.

Colectivo IOÉ (1998) Discapacidad y Trabajo en España. Madrid: Ministerio de Trabajo y Asuntos Sociales.

Colectivo IOÉ (2003) La inserció laboral de les persones amb discapacitats. Barcelona: Fundació la Caixa, Col·lecció d'Estudis Socials núm.14.

Departament Educació (2009) Resolució de 29 de maig relativa a l'organització $i$ funcionament dels centres educatius públics d'educació secundària per al curs 2009-2010. Generalitat de Catalunya

Echeita, G., Simon, C., Verdugo, M.A., Sandoval, M, López, M., Calvo, I. \& GonzalezGil, F. (2009) Paradojas y dilemas en el proceso de inclusión educativa en España. Revista de Educación, 349. 153-178. 
Escudero, J.M. (2005) Fracaso escolar, exclusión educativa: ¿De qué se excluye y cómo?. Profesorado, revista de currículum y formación del profesorado. 1(1), 1-24.

Escudero, J.M., González, M.T. \& Martínez, B. (2009) El fracaso escolar como exclusión educativa: comprensión, políticas y prácticas. Revista Iberoamericana de Educación. no 30, 41-61.

Hudson, B. (2006) Making and missing connections: learning disability services and the transition from adolescence to adult life. Disability \& Society, 21(1), 47-60.

Instituto Nacional de Estadística (2008) Encuesta de Discapacidad, Autonomía personal y situaciones de Dependencia. (http://www.ine.es/jaxi/menu.do?type=pcaxis\&path=\%2Ft15/p418\&file=inebase $\& \mathrm{~L}$ $=0)(2-12-09)$.

Instituto Nacional de Estadística (2009) Panorámica de la discapacidad en España. Encuesta de Discapacidad, Autonomía personal y situaciones de Dependencia. Cifras. Boletín Informativo del Instituto Nacional de Estadística, núm. 10. (http://www.ine.es/revistas/cifraine/1009.pdf) (24-2-10).

Jimenez Lara (2002) Los factores personales en el empleo de las personas con discapacidad. Empleo privado de las personas con discapacidad. In Documentos 61, pp. (41-51). Madrid: Real Patronato sobre Discapacidad- Ministerio de Asuntos Sociales.

Jordán, B., Verdugo, M.A. \& Vicent, C. (2005) Análisis de la evolución del Empleo con Apoyo en España. Real Patronato sobre Discapacidad. Documentos 59/2005. Madrid: Real Patronato sobre Discapacidad- Ministerio de Asuntos Sociales.

Kaehne, A. \& Beyer, S. (2009) Views of professionals on aims and outcomes of transition for young people with learning disabilities. British Journal of Learning Disabilities. 37, 138-144.

Kohler, P.D. \& Field, S. (2003) Transition-Focused Education: Foundations for the Future. The Journal of Special Education, 37(3), 174-183.

LISMI. Ley 13/1982 de 7 de Abril. Ley de Integración Social de los Minusválidos. Madrid: BOE de 30 de abril.

LOE. Ley Orgánica 2/2006, de 3 de mayo, de Educación. Ley de Ordenación del Sistema Educativo. Madrid: BOE de 4 de Mayo. 
LOGSE. Ley Orgánica 1/1990 de 3 de octubre. Ley de Ordenación General del Sistema Educativo. Madrid: BOE de 4 de octubre.

Martin, J.E., Van Dycke, J., D’Ottavio, M. \& Nickerson, K. (2007) The StudentDirected summary of performance: increasing Student and Family Involvement in the Transition Planning Process. Career Development for Exceptional Individuals, 30(1), 13-26.

Martínez Abellán, R., de Haro, R. \& Escarbajal, A. (2010) Una aproximación a la educación inclusiva en España. Revista de Educación Inclusiva. 3(1), 149-164.

Martínez Domínguez, B. (2005) Las medidas de respuesta a la diversidad: posibilidades y límites para la inclusión escolar y social. Profesorado, revista de currículum y formación del profesorado. 1(1) 1-31.

Pallisera, M., Fullana, J. \& Vilà, M. (2005) La inserción laboral de personas con discapacidad. Desarrollo de tres investigaciones acerca de los factores favorecedores de los procesos de inserción. Revista de Investigación Educativa, 23 (2), pp.295313.

Pallisera, M. \& Rius, M. (2007) ¿Y después del trabajo, qué? Más allá de la integración laboral de las personas con discapacidad. Revista de Educación, 342. 329-348.

Rius, M. (2005). Recerca sobre les persones amb discapacitat psíquica contractades a l'Administració de la Generalitat de Catalunya. Anàlisi de la incidència de la inserció laboral en diferents dimensions de la vida dels treballadors amb discapacitat psíquica. Doctoral disertation, Universitat de Girona.

Rusch, F.R, Hugues, C., Agran, M., Martin, J.E. \& Johnson, J.R. (2009) Toward SelfDirected Learning, Post-High School Placement, and Coordinated Support. Constructing New Transition Bridges to Adult Life. Career Developmental for Exceptional Individuals, 32(1) 53-59.

Sánchez Palomino, A. (2007) Investigación sobre la formación inicial del profesorado de secundaria para la atención educativa a los estudiantes con necesidades especiales. Revista Interuniversitaria de Formación del Profesorado. 21 (2/3), 149181.

Test, D.W., Mazzotti, V.L., Mustian, A.L., Fowler, C.H., Kortering, L. \& Kohler, P. (2009) Evidence-Based Secondary Transition Predictors for Improving Postschool 
Oucomes for Students With Disabilities. Career Development for Exceptional Individuals, 32(3), 160-181.

Trainor, A. (2008) Using Cultural and social Capital to Improve Postsecondary Outcomes and Expand Transition Models for Youth with Disabilities. The Journal of Special Education, 42(3), 148-162.

Verdugo, M.A. y Vicent, C. (2004) Evaluación de la Calidad de Vida en Empleo con Apoyo. Proyecto ALSOI. Salamanca: INICO.

Vilà, M., Pallisera, M. \& Fullana J. (2007) Work integration of people with disabilities in the regular labour market: What can we do to improve these processes?. Journal of Intellectual and Developmental Disability , 32(1), 10-18.

Vilà, M. (Dir); Fullana, J.; Pallisera, M.; Jiménez, P.; Cardona, M.; Rius, M. \& Santiago, J. (2008) Análisis de la formación para la inserción laboral de las personas con discapacidad en la etapa de educaci'n secundaria en España. Propuestas de actuación para la mejora de la formación sociolaboral. Proyecto financiado por el Ministerio de Educación y Ciencia (Período 2005-08). SEJ2005-01957/EDUC.

Wehmeyer, M.L. (1998) Teaching self-determination to students with disabilities. Basic skills for successful transition. Baltimore: Paul H. Brookes.

Wehmeyer, M. \& Schwartz, M. (1997) Self-Determination and positive adult outcomes: a follow-up study of youth with mental retardation or learning disabilities. Exceptional Children, 63(2), 245-255.

Wehmeyer, M.L. and Palmer, S.B. (2003) Adult outcomes for students with cognitive disabilities three-years after high schol: The impact of self-determination. Education and Training in Developmental Disabilities, 38, 131-144.

Winn, S. y Hay, I. (2009) Transition from school for youths with a disability: issues and challenges. Disability \& Society, 24(1), 103-115. 
Table 1: Distribution of pupils in the study according to how their educational care is organised.

\begin{tabular}{|l|c|}
\hline Type of schooling & Number of pupils \\
\hline $\begin{array}{l}\text { 1. Corresponding year class with no adaptation of the } \\
\text { curriculum }\end{array}$ & 0 \\
\hline $\begin{array}{l}\text { 2. Corresponding year class with adapted curriculum } \\
\text { studied in class }\end{array}$ & 2 \\
\hline $\begin{array}{l}\text { 3. Corresponding year class with adapted curriculum } \\
\text { studied outside class }\end{array}$ & 9 \\
\hline $\begin{array}{l}\text { 4. Corresponding year class combined with another } \\
\text { specialised group (at the same school) }\end{array}$ & 6 \\
\hline 5. Schooled mainly in a specialised group & 5 \\
\hline $\begin{array}{l}\text { 6. Schooling shared between ordinary school and special } \\
\text { school }\end{array}$ & \\
\hline
\end{tabular}

